\title{
Public Managers: Their Behavior, their Change Potential and the Behavior of Women and Men in Public Organizations
}

\author{
UDK: 35:005(045) \\ Jon Aurum Andersen \\ Lillehammer University College \\ jon.andersen@hil.no
}

\begin{abstract}
This survey article addresses three questions based on the assumption that significant differences exist between public and private organizations. If this assumption is correct managerial and leadership behavior will differ between public and private managers. Additionally, the propensity to change will also differ between public and private managers. Since a number of studies indicate that managers' leadership behavior in public organizations differ from that of private managers, difference and similarities in leadership behavior between women and men in public organizations are examined. Three studies are presented here which show that public and private managers have different behavioral patterns of leadership. However, public managers turn out to be more change-oriented than business managers. In the public organizations investigated no differences in leadership behavior between women and men were found.
\end{abstract}

Key words: leadership behavior, public and private organization, change-oriented behavior, gender

JEL: ZOO

\section{Introduction - public vs. private organizations}

There are two competing perspectives in the study of public and private organizations. The generic perspective contains the claim that no such differences exist. The public-private distinction perspective argues that there are significant differences between public and private organizations.

Researchers advocating the generic perspective claim that public and private organizations face similar constraints and challenges. Buchanan (1975) has held that these categories are not mutually exclusive. There is a constant need for clarification of the public-private distinction (Rainey, 1983). The problem

Andersen, J. A. (2012). Public Managers: Their Behavior, their Change Potential and the Behavior of Women and Men in Public Organizations. 
of defining public-private distinctions is not surprising because organizations range along a continuum of public-private control. Perry and Rainey (2001) have claimed that distinct characteristics of public organizations are merely myths, which need to be clarified or discarded through research. Vaillancourt Rosenau and Linder (2003) have noted that the distinction between the forprofit and nonprofit sectors is being questioned. In short, the authors suggest that recent events appear to be driving the two closer together. Many of the conventional distinctions between for-profits and nonprofits no longer apply.

Among the advocates of the public-private distinction, we find Rainey et al. (1976), who claimed that there is a divergence between public and private organizations. Cook (1998) has argued that it is the character of public administration as a political institution that should be at the center for the conception of public management. What makes public administration and public management public, and thus distinctive, is that politics of the most fundamental nature are at the heart of the enterprise. Cook pointed out that differences in external environments help us understand how public and private organizations function. Rainey and Bozeman (2000) refer to the almost universal agreement among scholars that public organizations have more complexity and ambiguity.

Perry and Rainey (2001) stated that the public-private distinction is a significant area of organizational research in need of further analysis. The "public-private difference stream of research concerns the roles that public and private organizations have in our society. Using this framework, researchers have found that the demands placed on public and private organizations vary to the extent that different practices are recommended for each sector (Nutt, 2006). Public-management scholarship has suggested that public organizations are fundamentally different from private organizations as a consequence of the functions they provide to society.

\section{Leadership behavior of public and private managers}

\subsection{Introduction}

In support of the generic perspective Rainey et al. (1995) have found that public and private managers differed little regarding the enforcement of rules, and have found no significant difference between the public and private managers in perceived goal ambiguity. Rainey and Bozeman (2000) have found that public managers do not differ from business managers in their perceptions of organizational formalization. Additionally, Vaillancourt Rosenau and Linder (2003) have argued that executives of nonprofits and forprofits face the same pressures, and they share the same incentives.

In support of the public-private distinction, Rainey et al. (1976) have stated that there are indications of a number of important differences between private and public organizations that cannot be ignored in managerial research. 
They claimed that there are significant differences in selection, management and motivation; and in controlling and measuring results between these managerial groups.

Bower (1977) has stated that public management is not just different in degree from corporate management, but is different in quality. The differences have important implications for public managers and how they view their jobs. Rainey et al. (1995) have found a striking difference between public and private managers on personnel rules and constraints. This finding is consistent with other studies. Public agencies show markedly higher levels of formalization of such functions as personnel and purchasing.

Bower (1977) has noted that although we know enough about management in the public sector to know that it is different from corporate management, we do not know nearly as much as we should. Twenty-five years later, Van Wart (2003) has pointed out the lack of empirical research on public leadership. Cook (1998) pointed out that differences in external environments help us understand how public and private organizations function and their respective managers act. Andersen (2010a) concluded that there are profound differences between public and private organizations. These differences lead to the first hypothesis: Differences between public and private organizations will induce differences in leadership behavior.

\subsection{Methodology}

Andersen (2010a) investigated two groups of public managers (managers of social-insurance agencies and public school principals) and a group of private managers (two samples). The analyses were based on data from 459 middle managers in four organizations in Sweden. Behavioral dimensions were investigated, including leadership style (task, relationship and change orientation), decision-making style (the functions of sensing, intuition, thinking and feeling), and motivational profile (achievement, affiliation and power motivation). Written, scientifically tested instruments were used.

\subsection{Findings and conclusions}

The hypothesis was partly supported as public managers' behavior differed from that of private managers in three out of four dimensions. The $\chi^{2}$ tests yielded significant differences between public and private managers regarding leadership styles and motivation-profile distributions. Public and private managers differ significantly in leadership behavior but not in decision-making styles. Senior officials in social-insurance offices mostly have the change-oriented leadership style. They are mostly intuitive types and have the achievement motivational profile. Most school principals have the change-oriented style. They are basically intuitive in their decision-making. The principals are also achievement-motivated. Business managers are predominantly relationship-oriented. They are basically intuitive when making 
decisions. As expected, private managers are power-motivated. It is worth noting that both public and private managers use intuition most frequently when making decisions. This is not the case for all kinds of organizational managers (Hansson \& Andersen, 2001). There are significant differences between public and private managers with respect to leadership style and motivational profile. This finding is contrary to Rainey (1989), who has claimed that there is no real distinction between public and private management.

An interesting result from this study is that the public managers as a group appear to have virtually the same behavioral patterns. Public managers have the change-oriented leadership style, make decisions by use of intuition and are achievement-motivated (Andersen, 2010a). The result is contrary to Van Wart (2003), who has pointed out that the differences between public leaders are far greater and more challenging than are the similarities.

The study of Andersen (2010a) has shown that there were significant differences between public and private managers in respect of leadership behavior, while public managers appear to have virtually the same behavioral patterns. These findings are interpreted and contextualized in the light of the tradition of public-private distinctions, which is primarily rooted in public administration. They can also be explained by the person-organization fit theories, which draw from the larger body of scholarship on private-sector management. Additionally, the criteria used when promoting employees to managerial positions may also explain the differences found.

\section{Change-oriented behavior in public and private managers}

\subsection{Introduction}

Understanding when, why and how organizations need to change and develop is primarily a managerial challenge and responsibility. In the literature on change management, change is regarded as a means of enhancing organizational performance and effectiveness. Schein (2002, p. 273) has rightly noted that "Leading change is one of the most important and difficult leadership responsibilities." Major changes, moreover, are hardly possible without strong involvement by management. Leadership may be crucial in implementing organizational change in the public sector (Fernandez \& Rainey, 2006; Dull, 2009).

This issue is becoming more important. Implementing radical change in any organization takes years and demands many integrative efforts (Walston \& Chadwick, 2003). In the public service in the last two decades, such rapid changes as privatization, outsourcing and downsizing have pressured both managers and employees not only to work more efficiently but also with diminishing resources (Rusaw, 2007). Public-sector organizations thus also operate in an environment of change and choice. Demands for accountability have never been higher, and market-like competition through contracting- 
Public Managers: Their Behavior, their Change Potential and the Behavior of Women and Men in Public Organizations

out and downsizing requires managers to pay constant attention to the improvement of systems and strategies for delivering services (Berry, 2007).

\subsection{Change-oriented behavioral}

The concept of managers' change-oriented behavior taps into some of the most well-established theories of leadership (Bass, 1990; Yukl, 2010). The concept comprises four behavioral dimensions: (1) Leadership style, the leader's behavior by task, relationship and change-orientation; (2) decisionmaking style, how managers typically make decisions by the functions of sensing, intuition, thinking and feeling; (3) operational demands, the focus on managers' perception of the most urgent demands within the organization, be they relationship, task or developmental demands; and (4) motivation profile, the relative strength of managers' achievement, affiliation and power motivation.

The dimensions of leadership style, decision-making style, motivational profile and operational demands comprise 13 factors. Four of these factors relate to the concept of change-oriented behavior, and the remaining captures other aspects of leadership behavior. Andersen (2010b) suggests a concept and a measurement of managers' change-oriented behavior related to the initiation and implementation organizational change. The argument is that managers have an optimal potential for achieving organizational changes if they have the change-centered style of leadership, are intuitive, recognize demands for change, and have power-motivated behavior.

The study of Andersen (2010b) has aimed at assessing whether or not there are differences between public and private managers' change-oriented behavior. O'Toole and Meier (2003) have addressed the question of stability or change in the public sector. Certain empirical evidence, though limited, has given reason to doubt the image of public managers' inclination to resist innovative behavior (Roessner, 1977). Innovative behaviors of governmental executives show that the supposed rigidity in the public sector is an unhelpful over-generalization (Doig \& Hargrove, 1987).

Stupak (1996) has argued that external factors of change make managerial decision-making more difficult in public organizations. Additionally, several scholars (e.g., Cook, 1998; Van Wart, 2003; Hanbury et al., 2004) have underlined the importance of decision-making for public managers. Moreover, Haveri (2006) has argued that complexity is a dominant characteristic of changes in local government, and that decision-making becomes difficult in times of change.

There is little research on the decision-making styles of public managers. Rainey $(1979,1983)$ and Baldwin $(1987)$ have found no differences in selfreported interest in innovation between middle public and private managers. Guyot (1962), comparing the motivation profiles of middle managers in 
business and in the federal government, has found no significant difference regarding power motivation.

No doubt, the major part of the research on leadership has focused on business managers. Private companies deal with fast-changing environments and technologies, and change is »the name of the game. "Managers advocate new and innovative changes in the face of fierce competition and an uncertain world and are expected to be more change-oriented than public managers. Consequently, this is the formulation of the second hypothesis: Business managers are more change-oriented than public managers.

\subsection{Methodology}

This section presents a concept and a measurement of managers' behavior related to the initiation and implementation of organizational change using data from 343 middle managers in two public agencies (social-insurance offices and senior secondary schools) and one private company (Andersen, 2010b). The behavioral dimensions investigated were (1) leadership style (task, relationship and change orientation), decision-making style (the functions of sensing, intuition, thinking and feeling), (3) operational demands (relationship, task or developmental demands); and (4) motivational profile (achievement, affiliation and power motivation). Again, written, scientifically tested instruments were used.

\subsection{Findings and conclusions}

The analysis failed to support the second hypothesis. Business managers were less change-oriented than managers in public organizations. In fact, public managers surpassed business managers in this respect. There was no significant difference between heads of social-insurance offices and school principals' change-related behavior. This study indicates that heads of socialinsurance offices are more change-oriented than other managers, and school principals also outdo business managers.

The main reason for the differences may relate to the fact that some areas of the public sector and some public agencies - at least in Sweden - have been subject to profound and continuous changes over the last ten years. As the study indicates that business managers' change-orientation is relatively low compared to the managers from two other organizations, further investigations are warranted.

Since the early 1970s, major changes have taken place in the Swedish public sector. The public sector has encountered both challenges (e.g., cutting down costs to reduce the burden of debt) and opportunities (e.g., new information technology) that have forced it to innovate. Yet it is not known whether and to what degree these innovations are due to internal or external forces or due to the public managers' initiative and behavior. 
The practical managerial significance of this study rests on the assumption that the key word for leadership in the near future is »change«. The ambition is to understand managers' actual behavior concerning the initiation and implementation of change. This study reveals that the managers investigated do differ significantly regarding their change-orientation. The successful implementation of organizational change may depend on having top and middle managers with this kind of behavior. An assessment of managers' change-orientation may thus be useful before implementing major organizational changes in the public sector (Andersen, 2010b).

\section{Leadership behavior of women and men in public organizations}

\subsection{Introduction}

The issue of gender and management has increasingly gained more attention of researchers. Some scholars have stressed the differences between women and men in leadership positions, claiming that female leaders are inherently different from male leaders. Fondas (1997, p. 275) has argued that »[...] gender is part of the very conceptualization of management«, and Brenner et al. (1989) assert that women possess certain characteristics, attitudes and temperaments. Yet they do not explain how these characteristics manifest themselves in managerial behavior.

Cole (2004) has noted that one problem with the notion of feminine leadership is the lack of data on how women actually behave in senior positions. Consequently, the purpose of this section is report on whether there are differences in leadership behavior between women and men - when only public managers are investigated - and to suggest explanations for whatever differences and similarities there may be.

Pounder and Coleman (2002) have presented probable influences on leadership behavior: gender, national culture, socialization (society and workplace), nature of organization and organizational demographics. This study explores two of these explanations: (1) the nature of organization and (2) organizational demographics. Vecchio (2002) has claimed that the absence of strong evidence of gender differences is probably reflective of organizational influences. Two studies by Andersen $(2010 a$, b) have found significant differences in leadership behavior between managers in private and public organizations. Additionally, the influence of organizational demographics has also been explored in relation to differences in gender distribution of all employees and gender distribution of managers in organizations.

Ferrario (1991) has found that female and male managers do not differ in task-oriented or people-oriented behavior. Gibson (1995) has reported that no gender differences were obtained on any leadership-style dimensions. On the other hand, Park (1996) has found strong support for the relationships 
between masculinity and task-oriented style and between femininity and relations-oriented style. Trinidad and Normore (2005) have claimed that the presence of feminine or masculine characteristics in leadership is related to the construct of gender. It appears that Trinidad and Normore (2005) have assumed that differences exist, and they have thus called for the formulation of a female-based leadership theory. A substantial body of research does not support this assertion, however.

It needs to be stressed that previous research on gender differences are predominantly based on data from private organizations. Previous research has also indicated that differences in leadership behavior are due to organizational differences identified by the private-public distinction theories (e.g., Rainey et al., 1976; Andersen, 2010a, b). In order to eliminate the effects on behavior due to organizational differences, the Andersen and Hansson's (2011) study only investigated public managers. Based on previous research on gender differences a third hypothesis is formulated: There are no differences in leadership behavior between men and women in managerial positions in the public sector.

\subsection{Methodology}

The behavioral dimensions investigated included leadership style (task, relationship and change orientation), decision-making style (the functions of sensing, intuition, thinking and feeling) and motivational profile (achievement, affiliation, and power motivation). Written, scientifically tested instruments were used.

In order to eliminate any effects of organizational differences on leadership behavior, this study had only public managers responding to scientifically tested questionnaires that measured their leadership style, decision-making style and motivational profile (Andersen \& Hansson, 2011). Statistical analyses were based on data from Swedish public managers in three organizations $(n=385)$.

\subsection{Findings and conclusions}

The analysis supported the third hypothesis. Virtually no significant differences in behavior between female and male managers were found. Regardless of whether there is a female or male majority of employees or a female or male majority of managers, no effect on leadership behavior occurs. A number of studies indicate that managers' behavior is different in different types of organizations. This study suggests, therefore, that independent of gender organizational and demographic characteristics modify leadership behaviors, thus explaining similarities in leadership behavior. Out of the 30 pair-wise comparisons of means for the samples consisting of 385 managers in three different organizations, only five comparisons (17 per cent) yield significant 
differences in leadership behavior between women and men as managers. In only one case is the significance at the level of one per cent.

Few significant differences in leadership behavior between women and men in management surfaced in the comparison between predominantly male-led organizations. No differences emerged in leadership behavior in the predominantly female-led ones. Similarly, there were no differences in leadership behavior in the comparisons between male-led organizations with a majority of female employees and female-led ones with a majority of women.

The questions about the importance of organizational differences and organizational influences on leadership behavior also warrant some comments. We should do well to consider whether the type of organization, namely, public or private, influences leadership behavior. Instead of gender, the type of organization in which managers operate may explain their behavior to a much larger extent. Additionally, we may consider whether differences in gender distribution of all employees and gender distribution of managers in organizations affect leadership behavior. The managerial profession contains a number of behaviors that appear to override the impact of gender (Fierman, 1990; Moss \& Jensrud, 1995). As theories that distinguish between private and public organizations point out, previous research indicates that the differences arise owing to the fact that managers are in charge of different organizations, which Hansson and Andersen (2008) and Andersen (2010a) have suggested on the basis of the same behavioral dimensions used in this study.

Andersen and Hansson (2011) have concluded - as have the majority of other studies - that no or only small and inconsistent differences in behavior exist. They suggest that organizational differences and characteristics modify the phenomenon of leadership itself, which would explain the similarities of behavior regardless of gender. In this respect, a germane development is the rising trend that emphasizes the need to help women and men move away from gender-based stereotypes (Ferrario, 1991). The knowledge that there are few or no differences in leadership behavior between women and men in the public sector may contribute to this movement.

\section{Conclusion}

Research based on the public-private distinction concerns the roles that public and private organizations have in our society. Public-management scholarship has suggested that public organizations are fundamentally different from private organizations as a consequence of the functions they provide to society. Using this framework, three studies are presented. 
If there are profound differences between public and private organizations, these differences may be the reason for differences in leadership behavior. Andersen (2010a) concluded that there are significant differences between public and private organizations.

No doubt, the major part of the research on leadership has focused on business managers. Private companies deal with fast-changing environments and technologies, and change is often associated with businesses. A comparison between public and private managers gave unexpected results. Business managers were less change-oriented than managers in public organizations. In fact, public managers surpassed business managers in this respect (Andersen, 2010b).

Research on gender differences is predominantly based on data from private organizations. Previous research has also indicated that differences in leadership behavior are due to organizational differences identified by the private-public distinction theories. In order to eliminate the effects on behavior due to organizational differences, the study of Andersen and Hansson's (2011) only investigated public managers. Virtually no significant differences in behavior between female and male managers were found. Regardless of whether there is a female or male majority of employees or a female or male majority of managers, no effect on leadership behavior occurs. Current research may help women and men move away from gender-based stereotypes in management.

Professor Dr. Jon Aarum Andersen holds two Master Degrees (Master of Business Administration and Master of Social Science) from Norway. He is Doctor of Economics from Lund University, Sweden. Dr. Andersen has written 14 university level textbooks and has 25 international research journal publications. He is professor of Business Administration (management) at Linnaeus University, Sweden (partly leave of absence) and full time professor at Lillehammer University college. 
Public Managers: Their Behavior, their Change Potential and the Behavior of Women and Men in Public Organizations

\section{References}

- Andersen, J. A. (2010). Public versus Private Managers. Public Administration Review 17(1), 131-141.

- Andersen, J. A. (2010b). Assessing Public Managers' Change-Oriented Behavior: Are Private Managers Caught in the Doldrums? International Journal of Public Administration 33(6), 335-345.

- Andersen, J. A. \& Hansson, P. H. (2011). At the End of the Road? On Differences between Women and Men in Leadership Behavior. Leadership \& Organization Development Journal 32(5), 328-441.

- Baldwin, J. N. (1987). Public versus private: Not that different, not that consequential. Public Personnel Management 16(2), 181-193.

- Bass, B. M. (1990). Bass Stogdill's handbook of leadership. New York: Free Press.

- Bower, J. L. (1977). Effective Public Management. Harvard Business Review 55(2), 131-140.

- Brenner, O. C., Tomkiewics, J. \& Schein, V. E. (1989). The Relationship between Sex Role Stereotypes and Requisite Management Characteristics Revisited. Academy of Management Journal 32(3), 662-669.

- Buchanan, B. (1975). Red Tape and the Service Ethic. Administration \& Society 6(4), 423-444.

- Cole, N. D. (2004). Gender Differences in Perceived Disciplinary Fairness. Gender, Work and Organization 11(3), 254-279.

- Cook, B. J. (1998). Politics, Political Leadership, and Public Management. Public Administration Review 58(3), 225-230.

- Doig, J. W. \& Hargrove, E. C. (1987). Leadership and Innovation. Baltimore: John Hopkins University Press.

- Dull, M. (2009). Results-Model Reform Leadership: Questions of Credible Commitment. Journal of Public Administration Research and Theory 19(2), 255-284.

- Fernandez, S. \& Rainey, H. G. (2006). Managing Successful Organizational

- Change in the Public Sector. Public Administration Review 66(2), 168-176.

- Ferrario, M. (1991). Sex Differences in Leadership Style: Myth or Reality? Women in Management Review \& Abstracts 6(3), 16-21.

- Fierman, J. (1990). Do Women Manage Differently? Fortune, 17 December, 115-118.

- Fondas, N. (1997). Feminization Unveiled: Management Qualities in Contemporary Writings. Academy of Management Review 22(1), 257-282.

- Gibson, C. (1995). An Investigation of Gender Differences in Leadership across Four Countries. Journal of International Business Studies 26(2), 225-279.

- Guyot, J. F. (1962). Government Bureaucrats Are Different. Public Administration Review 22(4), 195-202.

- Hanbury, G. L., Sapat, A. \& Washington, C. W. (2004). Know Yourself and Take Charge of Your Own Destiny: The "Fit Model" of Leadership. Public Administration Review 64(5), 566-576.

- Hansson, P. H. \& Andersen, J. A. (2008). Vicars as Managers Revisited: A Comparative Study. Nordic Journal of Religion and Society 21(1), 91-111.

- Haveri, A. (2006). Complexity in local government change. Public Management Review 8(1), 31-46.

- Moss, J. \& Jensrud, Q. (1995). Gender, Leadership, and Vocational Education. Journal of Industrial Teacher Education 33(1), 6-23. 
Jon Aurum Andersen

- Nutt, P. C. (2004). Prompting the Transformation of Public Organizations. Public Performance and Management Review 27 4), 9-33.

- O’Toole, L. J. \& Meier, K. J. (2003). Plus ça Change: Public Management, Personnel Stability, and Organizational Performance. Journal of Public Administration Research and Theory 13(1), 43-64.

- Park, D. (1996). Gender role, decision style and leadership style. Women in Management Review11(8), 13-17.

- Perry, J. L. \& Rainey, H. G. (2001). The Public-Private Distinction in Organization Theory: A Critique and Research Strategy. Academy of Management Review 13(2), 182-201.

- Pounder, J. S. \& Coleman, M. (2002). Women - better leaders than men? In general and educational management it still "all depends". Leadership \& Organization Development Journal 23(3), 122-133.

- Rainey, H. G. (1979). Perceptions of Incentives in Business and Government: Implications for Civil Service Reform. Public Administration Review 39(5), 440-48.

- Rainey, H. G. (1982). Reward Preferences among Public and Private Managers: In Search of Service Ethics. American Review of Public Administration 16(4), 288-302.

- Rainey, H. G. (1983). Public Agencies and Private Firms: Incentive Structure, Goals, and Individual Roles. Administration \& Society 15(2), 207-42.

- Rainey, H. G. (1989). Public Management: Recent Research on the Political Context and Managerial Roles, Structures, and Behaviors. Journal of Management 15(2), 229-50.

- Rainey, H. G., Backoff, R. W. \& Levine, C. H. (1976). Comparing Public and Private Organizations. Public Administration Review 36(2), 233-44.

- Rainey, H. G., Pandey, S. K. \& Bozeman. B. (1995). Research Note: Public and Private Managers' Receptions of Red Tape. Public Administration Review 55(6), 567-73.

- Rainey, H. G. \& Bozeman, B. (2000). Comparing Public and Private Organizations: Empirical Research and the Power of the A Priori. Journal of Public Administration Research and Theory 10(2), 447-69.

- Roessner, J. D. (1977). Incentives to innovate in public and private organizations. Administration \& Society 9(3), 341-365.

- Schein, E.H. (2002). Organizational Culture and Leadership. San Francisco: Jossey Bass.

- Stupak, R. J. (1996). Change dynamics and public management: Challenges and opportunities. International Journal of Public Administration 19(10), 16691685.

- Trinidad, C. \& Normore, A. H. (2005). Leadership and gender: a dangerous liaison? Leadership \& Organization Development Journal 26(7), 574-590.

- Vaillancourt Rosenau, P. \& Linder, S. H. (2003). Two Decades of Research Comparing for Profit and Nonprofit Health Provider Performance in the United States. Social Science Quarterly 84(2), 219-41.

- Van Wart, M. (2003). Public-Sector Leadership Theory: An Assessment. Public Administration Review 63(2), 214-228.

- Vecchio, R. P. (2002). Leadership and gender advantage. The Leadership Quarterly 13(6), 643-671. 
Public Managers: Their Behavior, their Change Potential and the Behavior of Women and Men in Public Organizations

- Walston, S. L. \& Chadwick, C. (2003). Perceptions and misperceptions of major organizational change in hospitals: Do change efforts fail because of inconsistent organizational perceptions of restructuring and reengineering? International Journal of Public Administration 26(14), 1581-1605.

- Yukl, G. A. (2010). Leadership in Organizations. Upper Saddle River, N. J.: Prentice-Hall. 


\section{JAVNI MENEDŽERJI: NJIHOVO VEDENJE, NJIHOVA PRIPRAVLJENOST ZA SPREMEMBE IN VEDENJE ŽENSK TER MOŠKIH V JAVNIH ORGANIZACIJAH}

Ključne besede: vodstveno vedenje, organizacija, kspremembam usmerjeno vedenje,
spol

Članek obravnava tri vprašanja ob predpostavki, da obstajajo pomembne razlike med organizacijami v javnem in zasebnem sektorju. Če ta predpostavka drži, potem se bo način upravljanja in vodenja javnih in poslovnih menedžerjev razlikoval. Prav tako se bo razlikovala njihova usmerjenost k spremembam. Ker številne raziskave nakazujejo, da se vodstveno vedenje menedžerjev v javnih organizacijah razlikuje od vedenja poslovnih menedžerjev, smo podrobneje preučili tudi razlike in podobnosti pri vodstvenem vedenju med ženskami in moškimi v javnih organizacijah. Članek predstavlja tri raziskave, ki kažejo različne vedenjske vzorce vodenja javnih menedžerjev in poslovnih menedžerjev. Ob tem pa se je izkazalo, da so javni menedžerji bolj usmerjeni k spremembam kot poslovni menedžerji. $V$ javnih organizacijah, ki smo jih preučili, nismo našli nikakršnih razlik v vodstvenem vedenju moških in žensk. 